\title{
Characterization and purification of mesentericin Y105, an anti-Listeria bacteriocin from Leuconostoc mesenteroides
}

\author{
Yann Héchard, ${ }^{1}$ Benoit DériJard, ${ }^{1}$ François Letellier $^{2}$ and Yves Cenatiempo ${ }^{1 *}$ \\ 'Institut de Biologie Moléculaire et d'Ingénierie Génétique, URA CNRS 1172, Université de Poitiers, 40 Avenue du \\ Recteur Pineau, 86022 Poitiers Cedex, France \\ ${ }^{2}$ Unité de Microbiologie Appliquée, IUT La Rochelle, 17000 La Rochelle, France
}

(Received 11 May 1992; revised 17 July 1992; accepted I September 1992)

\begin{abstract}
A Leuconostoc mesenteroides ssp. mesenteroides was isolated from goat's milk on the basis of its ability to inhibit the growth of Listeria monocytogenes. The antimicrobial effect was due to the presence in the culture medium of a compound, named mesentericin Y105, excreted by the Leuconostoc mesenteroides Y105. The compound displayed known features of bacteriocins from lactic acid bacteria. It appeared as a proteinaceous molecule exhibiting a narrow inhibitory spectrum limited to genus Listeria. The apparent relative molecular mass, as indicated by activity detection after SDS-PAGE, was 2.5-3.0 kDa. The bacteriocin was purified to homogeneity by a simple three-step procedure: a crude supernatant obtained from an early-stationary-phase culture in a defined medium was subjected to affinity chromatography on a blue agarose column, followed by ultrafiltration through a $5 \mathrm{kDa}$ cut-off membrane, and finally by reverse-phase HPLC on a $\mathrm{C}_{4}$ column. Microsequencing of the pure bacteriocin and of tryptic fragments showed that mesentericin Y105 is a 36 amino acid polypeptide whose primary structure is close to that of leucocin A-UAL 187, which contains an extra residue at the C-terminus and displays only two differences in the overlapping sequence. However, unlike leucocin A-UAL 187, mesentericin Y105 displayed a bactericidal mode of action.
\end{abstract}

\section{Introduction}

Antimicrobial activities of lactic acid bacteria have been widely investigated in the past 10 years (Daeschel, 1989; Piard \& Desmazeaud, 1991). Whereas broad-spectrum inhibition is generally attributed to organic acid production and/or to hydrogen peroxide, a narrow inhibitory spectrum, that includes mainly homologous strains, is displayed by some species. The latter effect is linked to the synthesis and the secretion of bacteriocins, i.e. molecules of proteinaceous nature, whose bactericidal or bacteriostatic activity is directed towards a limited number of bacterial species (Tagg et al., 1976; Klaenhammer, 1988). Increasing efforts have therefore been made to seek a large array of bacteriocin-producing strains and to characterize the bacteriocins as well as the target cells.

* Author for correspondence. Tel. (33) 49453722 ; fax (33) 49 453503.

The amino acid sequence data for mesentericin Y105 reported in this paper have been submitted to PIR and assigned the accession number A37328.
Several food-contaminating bacteria were identified as pathogens responsible for human diseases. The growing number of animal and human cases of listeriosis (Farber \& Peterkin, 1991) due to the presence of Listeria monocytogenes in meat (Johnson et al., 1990) and the fact that they are closely related to Lactobacillaceae led to the identification of anti-Listeria lactic acid bacteria.

Some antagonistic lactic acid bacteria strains delaying Listeria growth were identified (Harris et al., 1989; Stiles \& Hastings, 1991) including one Leuconostoc mesenteroides and two Leuconostoc gelidum (Harding \& Shaw, 1990; Daba et al., 1991; Hastings \& Stiles, 1991). Bacteriocin purification was in some cases achieved, but only a few primary structures were directly determined or deduced from their gene sequence, e.g. lactacin $F$ (Muriana \& Klaenhammer, 1991), helveticin J (Joerger \& Klaenhammer, 1990), lactocin S (Mortvedt et al., 1991), lactococcin A (Holo et al., 1991) and recently leucocin A-UAL 187 (Hastings et al., 1991). Among those well-characterized bacteriocins, only leucocin A-UAL 187 appears inhibitory to Listeria monocytogenes. The bacteriocin family seems largely heterologous, since its members fall into a wide molecular mass range (from 
$2.5 \mathrm{kDa}$ to approx. $60 \mathrm{kDa}$ ) as estimated by SDS-PAGE. The nature of the genetic determinants for bacteriocins, in spite of noticeable exceptions, e.g. helveticin $\mathbf{J}$ which is chromosomally produced (Joerger \& Klaenhammer, 1986), are plasmid linked. Plasmid-encoded immunity is also displayed by the bacteriocin-producing strains (Klaenhammer, 1988). Since microbially-produced compounds such as nisin can be declared safe for humans, further characterization of anti-Listeria bacteriocins is of great interest to the food industry.

In this report, a new bacteriocin-producing Leuconostoc mesenteroides strain Y105 isolated from goat's milk is described. The bacteriocin, named mesentericin Y105, appeared mainly inhibitory to Listeria monocytogenes. A crude preparation was first submitted to various chemical and physical treatments, then purified and sequenced.

\section{Methods}

Bacterial strains and media. Lactic acid bacteria were isolated from goat's milk. They were propagated $(1 \%, \mathrm{v} / \mathrm{v}$, inoculum) aerobically in lactobacilli MRS or M17 broth (Biokar, France) at $30^{\circ} \mathrm{C}$, and then tested for their ability to inhibit the growth of an indicator strain, namely Listeria monocytogenes E20. as previously described (Héchard et al., 1990). Listeria monocytogenes E20 (serotype 4), a strain of hospital origin, was grown aerobically in Tryptic Soy Broth (Difco) at $30^{\circ} \mathrm{C}$ for $16-20 \mathrm{~h}$ before use in the antagonism assay.

Preparation of bacteriocin extracts. The bacteriocin-producing strain was grown to the stationary phase by incubating at $30^{\circ} \mathrm{C}$ for $16 \mathrm{~h}$ in MRS or $24 \mathrm{~h}$ in a defined medium; $52.5 \mathrm{~g} \mathrm{l}^{-1}$ Methionine Assay Medium (Difco), $100 \mathrm{mg} \mathrm{l}^{-1}$ DL-methionine. The final $\mathrm{pH}$ of the culture was $4 \cdot 2$ (MRS) to $5 \cdot 0$ (defined medium). Crude extracts were prepared as follows. The culture was either used directly or adjusted to pH 6.8 with $\mathrm{NaOH}$. The bacteria were then removed by centrifugation $(6000 \mathrm{~g}, 10 \mathrm{~min})$ and the supernatant was passed through a $0.22 \mu \mathrm{m}$ Millex-GV filter (Millipore). A concentrated extract, used for SDS-PAGE, was obtained by adding ammonium sulphate to the crude extract to a concentration of $60 \%(w / v)$. After incubation for $2 \mathrm{~h}$ at $4{ }^{\circ} \mathrm{C}$ the precipitate was collected and dialysed using a membrane with a cutoff of $6000-8000 \mathrm{Da}$ (Spectrum), against $10 \mathrm{~mm}$-sodium phosphate buffer (pH 6.8).

Bacteriocin detection. Bacteriocin was detected by an antagonism well-diffusion method, inoculating $1 \%$ of the indicator strain L. monocytogenes E20 culture in Tryptic Soy buffered agar ( $\mathrm{pH} 7.3)$ to avoid acid inhibition: $30 \mathrm{~g} \mathrm{l}^{-1}$ Tryptic Soy Broth; $1.5 \mathrm{~g} \mathrm{l}^{-1} \mathrm{KH}_{2} \mathrm{PO}_{4}$; $3.5 \mathrm{~g} \mathrm{l}^{-1} \mathrm{Na}_{2} \mathrm{HPO}_{4} ; 15 \mathrm{~g} \mathrm{l}^{-1}$ agar (Héchard et al., 1990). Wells were punched in the agar plate and filled with $100 \mu$ lof test samples. After overnight incubation at $30^{\circ} \mathrm{C}$, zones of inhibition were examined and their radii were measured.

Activity assay and spectrum. Mesentericin Y105 activity was estimated by the critical dilution method. Serial two-fold dilutions of bacteriocin extracts were tested by the well-diffusion method described above. The titre, expressed in activity units per millilitre (AU ml-1), was defined as the reciprocal of the highest dilution showing a radius of inhibition zone greater than $1 \mathrm{~mm}$.

The well-diffusion method was used to examine the antimicrobial activity of crude mesentericin Y105 extracts towards several Gramnegative or Gram-positive bacteria, such as food-spoilage and lactic acid organisms from the collection of the Institut Universitaire de
Technologie (La Rochelle, France) or Listeria strains kindly provided by P. Cossart (Laboratoire de Génétique Moléculaire des Listeria, Institut Pasteur, Paris, France). These strains were subcultured in the appropriate medium and then inoculated in the agar medium.

Protease, heat and storage stability. Crude extracts of mesentericin $\mathrm{Y} 105$, at the $\mathrm{pH}$ of the culture or adjusted to $\mathrm{pH} 6.8$, were independently submitted to either (i) $2 \mathrm{~h}$ in the presence of different proteases $\left(1 \mathrm{mg} \mathrm{ml}^{-1}\right)$ : pronase, proteinase $\mathrm{K}$, trypsin, chymotrypsin and pepsin purchased from Boehringer Mannheim, (ii) heating for 30, 60 and $120 \mathrm{~min}$ at $60^{\circ} \mathrm{C}$ and $100^{\circ} \mathrm{C}$ and sterilization for $30 \mathrm{~min}$ at $121^{\circ} \mathrm{C}$, or (iii) storage at $-20^{\circ} \mathrm{C},+4^{\circ} \mathrm{C}$ and at room temperature, with or without a 30 min pre-treatment at $95^{\circ} \mathrm{C}$. The biological activity of the different samples was then determined by the activity assay.

Purification of mesentericin Y105. A crude extract obtained after culturing in defined medium $(540 \mathrm{ml}, \mathrm{pH} 5.0)$ was loaded onto an affinity chromatography column $\left(30 \mathrm{ml}\right.$ of $1 \mu \mathrm{m} \mathrm{ml}^{-1}$ Blue Agarose, Kem-En-Consult, Hellerup, Denmark). The column was first washed with $20 \mathrm{~mm}$-acetate buffer, $\mathrm{pH} 5 \cdot 0$, to remove unbound proteins. Mesentericin $\mathrm{Y} 105$ was then eluted with $1 \mathrm{M}-\mathrm{NaCl}$ in the same buffer. Fractions were collected and tested by the well-diffusion method. Those displaying bacteriocin activity were assembled and concentrated in a Minitan ultrafiltration system (Millipore) with a $5 \mathrm{kDa}$ cut-off membrane. The retentate was dialysed against water to remove the salts, and finally evaporated in a Speed-vac concentrator. The bacteriocin was further purified by reverse-phase HPLC on a $25 \mathrm{~cm}$ Nucleosil $300 \AA \mathrm{C}_{4}$ column (Colochrom), using a 6 to $60 \%(\mathrm{v} / \mathrm{v})$ acetonitrile gradient. Buffers were as follows: (A) $0.1 \%$ trifluoroacetic acid (TFA), (B) $60 \%(\mathrm{v} / \mathrm{v})$ acetonitrile in $0.1 \%$ TFA. Elution of proteins was performed by running a 60 min gradient from $90 \% \mathrm{~A} / 10 \%$ B to $100 \%$ B $\left(0.8 \mathrm{ml} \mathrm{min}^{-1}\right)$. Fractions were tested for anti-Listeria activity, and then evaporated in a Speed-vac concentrator. A part of the sample was kept for direct sequencing while the rest was subjected to trypsin digestion.

Trypsin digestion. About $11 \mu \mathrm{g}$ of pure mesentericin Y105 was treated with $0.4 \mu \mathrm{g}$ trypsin TPCK (Sigma) in $200 \mu \mathrm{l} 0.1 \mathrm{M}$-ammonium bicarbonate buffer at $\mathrm{pH} 7.8$. After $10 \mathrm{~h}$ at $37^{\circ} \mathrm{C}$, the sample was directly applied to a reverse-phase HPLC $\mathrm{C}_{4}$ column as described above for intact mesentericin. Individual tryptic fragments were collected, evaporated and sequenced.

Amino acid sequence determination. The amino-terminal sequence analysis of the protein and of the tryptic peptides was performed by L. Denoroy at the Service Central d'Analyse, Centre National de la Recherche Scientifique, Vernaison, France.

$S D S-P A G E$. The apparent molecular mass of mesentericin Y 105 was estimated by Tricine-SDS-PAGE, done on $0.75 \mathrm{~mm}$ gels as described by Schägger \& Von Jagow (1987). Concentrating and separating gels were separated by a spacer gel. The polyacrylamide concentration of the 3 gels was $4,16.5$ and $10 \%(w / v)$, respectively. The separating gel contained $10 \%(\mathrm{v} / \mathrm{v})$ glycerol. Migration was performed in a vertical slab gel apparatus (Mighty small, Hoeffer Instruments), at a constant voltage $(150 \mathrm{~V})$ for approximately $2 \mathrm{~h}$. Part of the gel was silver-stained (Giulian et al., 1983) while the other was assayed for antimicrobial activity by direct test as previously described (Bhunia et al., 1987).

\section{Results}

\section{Isolation of bacteriocin producing strains}

Out of 120 goat's milk samples screened, 64 lactic acid bacteria were isolated on the basis of Gram stain, catalase and oxidase tests. They were screened for their 
Table 1. Activity of crude mesentericin Y105 extract toward different indicator bacteria

\begin{tabular}{|c|c|c|c|}
\hline Species* & Sensitivity† & Species* & Sensitivity† \\
\hline Yersinia enterocolitica $\mathrm{C} 123$ & - & Listeria monocytogenes E20 & ++ \\
\hline Campylobacter jejuni D46 & - & Listeria monocytogenes BOF344 & ++ \\
\hline Proteus vulgaris $\mathrm{C} 74$ & - & Listeria monocytogenes BUG31 & ++ \\
\hline Klebsiella pneumoniae $\mathrm{C} 65$ & - & Listeria ivanovii BUG496 & $++t$ \\
\hline Staphylococcus aureus A15 & - & Listeria ivanovii BUG497 & +++ \\
\hline Salmonella enteritidis $\mathrm{C} 83$ & - & Listeria ivanovii BUG598 & $++t$ \\
\hline Salmonella paratypi B C93 & - & Listeria seeligeri BUG494 & + \\
\hline Micrococcus luteus A04 & - & Listeria seeligeri BUG495 & ++ \\
\hline Streptococcus faecalis B05 & - & Listeria seeligeri BUG599 & ++ \\
\hline Lactococcus lactis G04 & - & Listeria innocua BUG498 & + \\
\hline Lactobacillus brevis G07 & - & Listeria innocua BUG499 & ++ \\
\hline Pediococcus acidilactici G06 & - & Listeria welshimeri BUG501 & ++ \\
\hline Bacillus megaterium F04 & - & Listeria welshimeri BUG502 & + \\
\hline Bacillus cereus $\mathrm{F} 02$ & - & Listeria murrayi BUG503 & $+1-$ \\
\hline Bacillus stearothermophillus F07 & - & & \\
\hline
\end{tabular}

* Source of strains: All Listeria stains were from the laboratory of 'Génétique Moléculaire des Listerias', Institut Pasteur, Paris. All other strains were from the collection of the 'Institut Universitaire de Technologie', La Rochelle.

† Sensitivity was estimated for each strain by the well-diffusion test described in Methods. Radius of the inhibition zone was measured:,$- 0 \mathrm{~mm} ;+/-, 1 \mathrm{~mm} ;+, 1.5$ to $3 \mathrm{~mm} ;++, 3.5$ to $4.5 \mathrm{~mm} ;+++$, $>4.5 \mathrm{~mm}$.

ability to inhibit the growth of L. monocytogenes E20. A new antagonistic strain was obtained which obviously produced a bacteriocin, because lactic-acid-related inhibition was minimized by the use of a buffered medium. Identification of this strain was conducted by testing its fermentation patterns with an API 50 test and by showing its heterofermentative character. Further characterization, performed by the Deutsche Sammlung von Mikroorganismen (DSM, Germany), showed that the bacteriocin-producing strain was a Leuconostoc mesenteroides $\mathrm{ssp}$. mesenteroides named Y105. Therefore the bacteriocin was termed mesentericin Y105. The growth of Leuconostoc mesenteroides Y105 was followed for $24 \mathrm{~h}$ at $30^{\circ} \mathrm{C}$ in MRS medium. An increase in the antagonism activity of the culture supernatant (i.e. bacteriocin excretion) occurred continuously after a lag period of $3 \mathrm{~h}$, until the late exponential phase, and production of the mesentericin $\mathrm{Y} 105$ was higher at $30^{\circ} \mathrm{C}$ than at $37^{\circ} \mathrm{C}$ (data not shown).

\section{Inhibitory spectrum}

The inhibitory spectrum of mesentericin Y105 was assessed by testing its efficiency toward various Gramnegative and Gram-positive bacteria, including other lactic acid bacteria and several pathogenic strains. Table 1 shows that the bacteriocin produced is specific for Listeria genus. All of the Listeria strains were inhibited when tested by the well-diffusion test. Some Listeria ivanovii ssp. were highly sensitive to the bacteriocin as compared with our reference strain $(L$. monocytogenes E20). On the other hand, Listeria murrayi BUG 503 displayed a minimal response. Neither the Gramnegative and other Gram-positive indicator bacteria, nor the related lactic acid bacteria species were inhibited within the limits of detection of the assay. Therefore it was concluded that the producer strain had a narrow inhibitory spectrum limited to Listeria.

\section{Properties of mesentericin Y105}

Crude mesentericin $\mathrm{Y} 105$ extract was adjusted to $\mathrm{pH} 4.5$ or 6.8 and submitted to various conditions: protease treatment, heat (Fig. 1) and storage at different $\mathrm{pH}$ and temperatures. The activity was then measured by the well-diffusion test. All of the proteolytic enzymes tested (pronase, proteinase $\mathrm{K}$, trypsin, chymotrypsin and pepsin; $1 \mathrm{mg} \mathrm{ml}^{-1}$ ) totally inhibited the activity after $2 \mathrm{~h}$ treatment, except the sample of crude extract (pH 6.8) treated with pepsin, which remained active, probably because this protease is normally inhibited at $\mathrm{pH}>6$ (Fig. 1). The bacteriocin remained active after $120 \mathrm{~min}$ at $60^{\circ} \mathrm{C}\left(320 \mathrm{AU} \mathrm{ml}^{-1}\right)$. Higher temperature treatment showed that mesentericin Y105 was more stable under initial conditions at $\mathrm{pH} 4.5$ than in a medium adjusted to pH 6.8. Samples at $\mathrm{pH} 4.5$ had to be autoclaved or treated at $100^{\circ} \mathrm{C}$ for $120 \mathrm{~min}$ to lose part of their activity $\left(80 \mathrm{AU} \mathrm{ml}^{-1}\right)$, whereas activity of samples at $\mathrm{pH} 6.8$ 

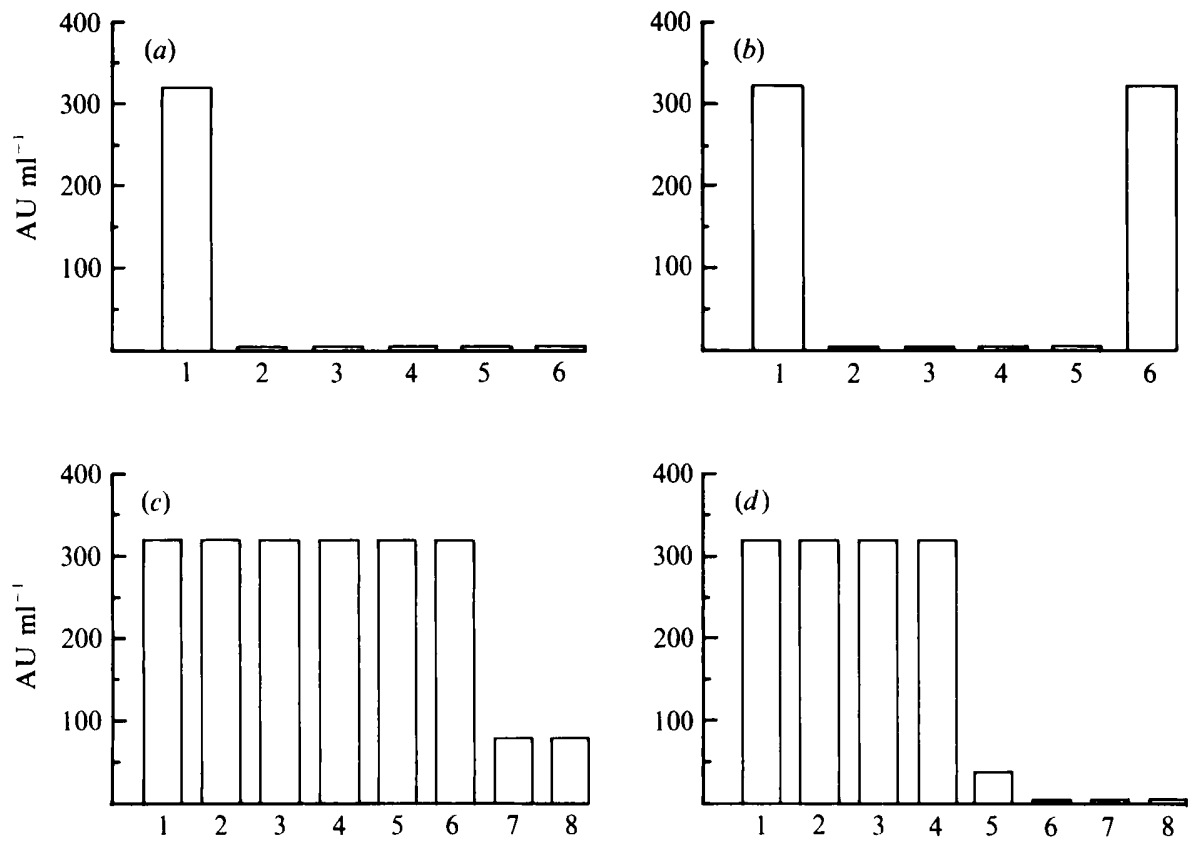

Fig. 1. Mesentericin Y105 stability. Crude bacteriocin extract was treated with proteases at $(a) \mathrm{pH} 4.5$ and $(b) \mathrm{pH} 6.8: 1$, control; 2, pronase; 3, proteinase $\mathrm{K} ; 4$, trypsin; 5 , chymotrypsin; 6, pepsin. $(c, d)$ Heat treatment at pH 4.5 and 6.8 , respectively: 1 , control; $2,30 \mathrm{~min}$ at $60^{\circ} \mathrm{C} ; 3,60 \mathrm{~min}$ at $60^{\circ} \mathrm{C} ; 4,120 \mathrm{~min}$ at $60{ }^{\circ} \mathrm{C} ; 5,30 \mathrm{~min}$ at $100^{\circ} \mathrm{C} ; 6,60 \mathrm{~min}$ at $100{ }^{\circ} \mathrm{C} ; 7,120 \mathrm{~min}$ at $100{ }^{\circ} \mathrm{C} ; 8,30 \mathrm{~min}$ at $121^{\circ} \mathrm{C}$.

decreased to $40 \mathrm{AU} \mathrm{m} \mathrm{ml}^{-1}$ after only $30 \mathrm{~min}$ at $100{ }^{\circ} \mathrm{C}$ (Fig. 1). When stored for 4 weeks at $-20^{\circ} \mathrm{C}$, mesentericin Y105 kept its activity (data not shown). Long term storage at $-20^{\circ} \mathrm{C}$ indicated that bacteriocin was active for at least 6 months. At $4{ }^{\circ} \mathrm{C}$, the bacteriocin had to be stabilized by preliminary heat treatment and low $\mathrm{pH}$, whereas storage at room temperature was not appropriate, because rapid loss of activity occurred. These experiments demonstrated that the inhibitory activity was due to a proteinaceous molecule sensitive to proteases but exhibiting excellent heat stability and stability under acidic conditions. The heat tolerance suggested the mesentericin to be a low-molecular-mass bacteriocin.

\section{Estimation of molecular mass}

SDS-PAGE was used to estimate the molecular mass of mesentericin Y105. Silver stain and other dyes such as Coomassie blue $\mathbf{R} 250$ are poorly bound by mesentericin Y105. Therefore, direct detection via its activity in SDSpolyacrylamide gels appeared to be a better method provided it was not affected by the detergent. Fig. 2 shows that the apparent molecular mass could be estimated in this way to be $2 \cdot 5-3.0 \mathrm{kDa}$. Moreover, since its biological activity remained after SDS-PAGE, it seems that this protein is either refractory to detergent action, or able to renature during the assay.

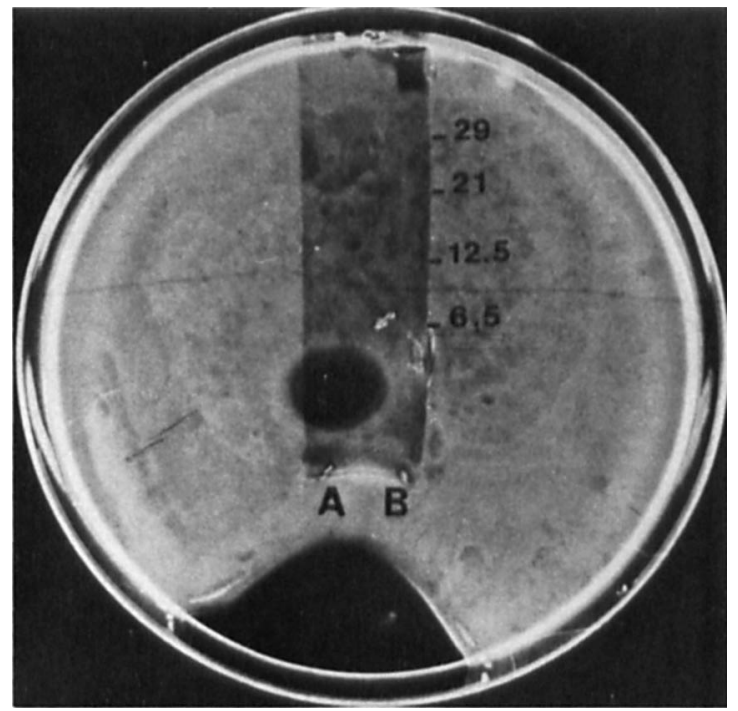

Fig. 2. Direct detection of mesentericin after SDS-PAGE. Polyacrylamide gel was recovered with Listeria monocytogenes seeded agar and inhibition was detected after $16 \mathrm{~h}$. (A) Lane containing the bacteriocin extract. (B) Control (electrophoresis sample buffer). Sizes of molecular mass markers in $\mathrm{kDa}$.

\section{Purification}

Mesentericin Y105 was purified from the supernatant fractions of cultures prepared in defined medium to minimize the presence of contaminating proteins and 


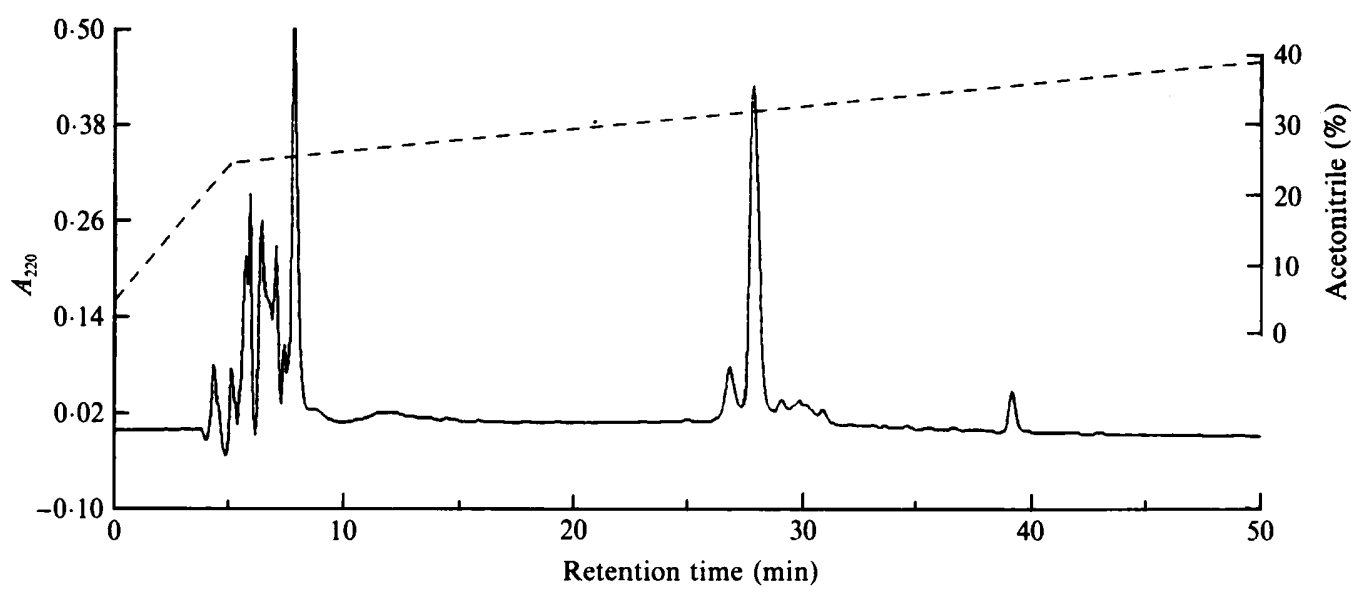

Fig. 3. Reverse-phase $\left(C_{4}\right)$ HPLC chromatogram of ultrafiltered sample monitored by $A_{220}$. The major peak with a 28 min retention time exhibited anti-Listeria activity. ---, Acetonitrile concn.

Table 2. Purification of mesentericin Y105

\begin{tabular}{lcccccc}
\hline \hline \multicolumn{1}{c}{ Sample } & $\begin{array}{c}\text { Vol. } \\
(\mathrm{ml})\end{array}$ & $\begin{array}{c}\text { Concn* } \\
\left(\mu \mathrm{g} \mathrm{ml}^{-1}\right)\end{array}$ & $\begin{array}{c}\text { Activity } \\
\left.(\mathrm{AU} \mathrm{ml})^{-1}\right)\end{array}$ & $\begin{array}{c}\text { Spec. Act. } \\
\left.(\mathrm{AU} \mathrm{mg})^{-1}\right)\end{array}$ & $\begin{array}{c}\text { Purification } \\
(- \text { fold })\end{array}$ & $\begin{array}{c}\text { Activity } \\
\text { recovered (\%) }\end{array}$ \\
\hline Crude extract & 540 & 1885 & 20 & $10 \cdot 6$ & 1 & 100 \\
Affinity chromatography & 370 & $3 \cdot 6$ & 30 & $8333 \cdot 3$ & $778 \cdot 9$ & 100 \\
After storaget & 370 & $3 \cdot 6$ & 5 & $1388 \cdot 8$ & $131 \cdot 0$ & $16 \cdot 2$ \\
Ultrafiltration & 65 & $9 \cdot 5$ & 20 & $2105 \cdot 2$ & $198 \cdot 6$ & 12 \\
Reverse phase & 1 & 18 & 80 & $4444 \cdot 4$ & $419 \cdot 2$ & $0 \cdot 7$ \\
\hline \hline
\end{tabular}

* Protein concentration $\left(\mathrm{mg} \mathrm{ml}^{-1}\right)$ was estimated by $A_{220} / 11$ (Scopes, 1988).

$\dagger$ The activity of the sample arising from affinity chromatography was reassessed at the same time as the ultrafiltered fraction.

peptides. The crude supernatant fraction was loaded onto an affinity chromatography column. This first step greatly increased the specific activity $(\times 779)$ because the column retained only a very small amount of supernatant proteins, among which was the mesentericin Y105. However, after this initial step, the specific activity of the bacteriocin fraction dramatically dropped by approx. $80 \%$ when left for $8 \mathrm{~h}$ at $4{ }^{\circ} \mathrm{C}$. The sample was concentrated by ultrafiltration and then dialysed to lower its salt content. Both ultrafiltration and dialysis led to a loss of activity compared to the preceding purification step, as indicated in Table 2 . In spite of this decline, ultrafiltration through a membrane with a cut-off of $5 \mathrm{kDa}$ allowed the removal of small peptides, whereas the bacteriocin behaved as a higher molecular mass peptide, possibly due to multimerization or association with macromolecules. The final step was reverse-phase HPLC. The bacteriocin was retained under initial conditions and then eluted with $32 \%(\mathrm{v} / \mathrm{v})$ acetonitrile under a major peak (Fig. 3). Its protein content was estimated by UV absorption at $220 \mathrm{~nm}$. According to UV spectrum analysis $(205-230 \mathrm{~nm})$ of the peak using the Focus program (Spectra-Physics), the bacteriocin was considered purified to homogeneity. Part of the pure mesentericin Y105 sample was used for trypsin digestion, followed by HPLC separation of 4 peptides (data not shown).

\section{Primary sequence}

The amino-terminal analysis of the complete protein gave the amino acid sequence appearing in Fig. 4. After 36 amino acid residues, no other phenylthiohydantoinderivatized residues became detectable after 10 additional cycles. Morever, this sequence was confirmed by the following tryptic peptides: (1) $\mathrm{H}_{2} \mathrm{~N}$-Lys-Tyr-TyrGly-Asn-Gly-Val-His-Cys-Thr-Lys-Ser-Gly-Cys-SerVal-Asn-Trp-Gly-Glu-Ala-Ala-Ser-Ala-Gly-Ile-HisArg-; (2) $\mathrm{H}_{2} \mathrm{~N}$-Lys-Tyr-Tyr-Gly-Asp-Gly-Val-His-CysThr-Lys-Ser-Gly-; (3) $\mathrm{H}_{2} \mathrm{~N}$-Leu-Ala-Asn-Gly-Gly-AsnGly-Phe; (4) apparently a mixture of $\mathrm{H}_{2} \mathrm{~N}$-Ser-Gly-CysSer-Val-Asn-Trp-Gly-Glu-Ala-Ala-Ser-Ala-Gly-Ile-HisArg- and $\mathrm{H}_{2} \mathrm{~N}$-Lys-Tyr-Tyr-Gly-Asn-Gly-Val-His-CysThr-Lys-. Whereas the first peptide and those in the 
1

5

10

LYS - TYR - TYR - GLY - ASN - GLY - VAL - HIS - CYS - THR -

11

15

20

LYS - SER - GLY - CYS - SER - VAL - ASN - TRP - GLY - GLU -

21

25

30

ALA - ALA - SER - ALA - GLY - ILE - H IS - ARG - LEU - ALA -

- PHE

VAL

31

35

ASN - GLY - GLY - ASN - GLY - PHE

TRP

Fig. 4. Amino acid sequence of the mesentericin Y105 (upper line) compared with that of leucocin A-UAL 187 (lower line). Dashes in leucocin sequence indicate residues identical to those found in mesentericin.

mixture ending with Lys or Arg correspond to expected cleavage sites by trypsin, the second peptide with a carboxy-terminal Gly results from a non-specific cut and the third is obviously the carboxy-terminal part of mesentericin Y105. Its calculated molecular mass on the basis of amino acid sequence is $3666 \cdot 6 \mathrm{Da}$.

\section{Discussion}

Mesentericin Y105 is the first bacteriocin, inhibiting growth of Listeria monocytogenes, which is produced by a Leuconostoc mesenteroides ssp. mesenteroides, isolated from goat's milk. Hastings et al. (1991) recently described a bacteriocin, leucocin A-UAL 187, produced by a Leuconostoc gelidum isolated from vacuum-packaged meat, that shows a strong similarity with mesentericin Y105. It is noticeable that the leucocin-A-UAL187-producing strain was originally identified as a Leuconostoc mesenteroides ssp. mesenteroides and later it was classified as a Leuconostoc gelidum (Hastings \& Stiles, 1991). This is not the case here, since this strain belongs to mesenteroides not gelidum, because it ferments galactose but not amygdalin nor ribose according to an API $50 \mathrm{CH}$ test. Another difference between these Leuconostoc bacteria lies in their inhibitory spectra. Unexpectedly, mesentericin Y105 has an extremely narrow spectrum of activity. All of the 14 strains of Listeria spp. tested showed variable susceptibility to the bacteriocin which does not inhibit any of the Gramnegative or Gram-positive strains tested, even closely related lactic acid bacteria. Moreover, mesentericin Y105 appeared bactericidal to Listeria monocytogenes E20 (unpublished results) whereas leucocin A-UAL 187 seems to have a wider range of action and a bacteriostatic activity. Daba et al. (1991) also described a small bacteriocin $(4.5 \mathrm{kDa})$ produced by a Leuconostoc mesenteroides with a narrow range of activity principally directed toward genus Listeria, but its primary sequence is not yet known.

The general properties of mesentericin are characteristic of the particular family of low-molecular-mass bacteriocins. It remains active at low $\mathrm{pH}$ and is unaffected by heat treatment, similar to most of these peptides (Hasting \& Stiles, 1991). We observed that heat pre-treatment of crude extract seems to stabilize the activity. This may be due to the denaturation of proteases which could also be produced by the Leuconostoc mesenteroides. As described by Merill (1990), some proteins are difficult to stain for unknown reasons. Therefore, detection was achieved by a direct activity assay as described by Bhunia et al. (1987) after TricineSDS-PAGE (Shägger \& Von Jagow, 1987). According to this assay, mesentericin Y105 has a molecular mass of $2.5-3.0 \mathrm{kDa}$. Like some bacteriocins (Joerger \& Klaenhammer, 1986; Mortvedt et al. 1991), mesentericin Y105 seems to aggregate with other substances under non-denaturing conditions or simply associates into polymer forms. Whether this phenomenon affects its biological activity is not yet known.

Although production of this bacteriocin was consistently higher $(\times 16)$ in MRS medium, the specific activity of crude extracts was lower than in the defined medium. As a consequence, the latter was chosen to simplify the purification process. For the first step, the 'Mimetic Blue l'was first selected from 10 different dyes from the Piksi System (ACL, Cambridge, UK). It was later substituted by a similar dye, 'Blue agarose', which displayed a higher specificity for the bacteriocin. The use of a defined medium linked to dye-affinity-chromatography is the main feature of this process leading to pure mesentericin in a simple manner. By comparison, leucocin A-UAL 187 purification was conducted by an ammonium sulphate precipitation followed by three steps of chromatography (Hastings et al., 1991). Thus, the scheme described here opens up the possibility for scaling-up mesentericin preparation in order to use this bacteriocin in structural studies or even as a food preservative. However, the problem of the stability of the activity after the first chromatography step has to be addressed. Different protease inhibitors were tested without delaying the loss of activity (data not shown), so it is unlikely to be due to bacteriocin proteolysis. Inactivation of 
mesentericin Y105 could also result from a specific effect on the catalytic site, such as loss of cofactors or covalent modifications. Moreover, early studies described a quick loss of activity with very dilute enzymes.

Finally, reverse-phase HPLC yields pure bacteriocin. This sample and its tryptic fragments were directly used for protein sequencing leading to the total sequence of mesentericin Y105. Comparison with the primary structure of other proteins (EMBL data bank) indicates that mesentericin Y 105 sequence (36aa) is close to that of leucocin A-UAL 187 (Hastings et al., 1991) which contains an extra tryptophan residue at the carboxyterminus and displays only two differences in the sequence, a phenylalanine and a valine in place of alanine-22 and isoleucine-26, respectively.

Finally, it will be very interesting to investigate the mesentericin Y105 target selection and mode of action. It is not yet known whether a specific membrane receptor is involved as described for colicins (Pattus et al., 1990) and recently suggested by Van Belkum et al. (1991) for lactococcin A produced by a Lactococcus lactis, or, like some lantibiotics, targeting is driven by a particular phospholipid composition of cytoplasmic membranes (Kordel et al., 1988; Gao et al., 1991). Flow cytometry and oxymetry analysis (unpublished results) indicate that mesentericin Y105 decreases membrane potential and oxygen consumption of Listeria cells. Studies are in progress to understand the mode of action of these bacteriocins at the molecular level.

This study was supported by the Ministère de la Recherche et de la Technologie, contract no. $90 \mathrm{H0128}$. We thank Nadine Retailleau and Didier Renault for their technical assistance and Yannis Karamanos, Antoine Delfour and Pierre Aucouturier for their technical advice. We are grateful for the use of the technical facilities of URA CNRS 1452. We also thank Pascale Cossart for the gift of Listeria strains and T. C. Bog Hansen for the gift of 'Blue agarose' samples.

\section{References}

Bhunia, A. K., Johnson, M. C. \& Ray, B. (1987). Direct detection of an antimicrobial peptide of Pediococcus acidilactici in sodium dodecyl sulfate-polyacrylamide gel electrophoresis. Journal of Industrial Microbiology 2, 319-322.

Daba, H., Pandian, S., Gosselin, J. F., Simard, R. E., Huang, J. \& LACROIX, C. (1991). Detection and activity of a bacteriocin produced by Leuconostoc mesenteroides. Applied and Environmental Microbiology 57, 3450-3455.

Daeschel, M. A. (1989). Antimicrobial substances from lactic acid bacteria for use as food preservatives. Food Technology 43, 164-167.

Farber, J. M. \& PETERKIN, P. I. (1991). Listeria monocytogenes, a foodborne pathogen. Microbiological Reviews 55, 476-511.

GaO, F. H., Abee, T. \& Konings, W. N. (1991). The mechanism of action of the peptide antibiotic nisin in liposomes and cytochrome $c$ oxidase-containing proteoliposomes. Applied and Environmental Microbiology 57, 2164-2170.

Giulian, G. G., Moss, R. L. \& Greaser, M. (1983). Improved methodology for analysis and quantitation of proteins on onedimensional silver-stained slab gels. Analytical Biochemistry 129, 277-287.
HaRding, C. D. \& SHaw, B. G. (1990). Antimicrobial activity of Leuconostoc gelidum against closely related species and Listeria monocytogenes. Journal of Applied Bacteriology 69, 648-654.

Harris, L. J., Daeschel, M. A., Stiles, M. E. \& Klaenhammer, T. R. (1989). Antimicrobial activity of lactic acid bacteria against Listeria monocytogenes. Journal of Food Protection 52, 384-387.

Hastings, J. W. \& Stiles, M. E. (1991). Antibiosis of Leuconostoc gelidum isolated from meat. Journal of Applied Bacteriology 70, 127-134.

Hastings, J. W., Sailer, M., Johnson, K., Roy, K. L., Vederas, J. C. \& STILES M. E. (1991). Characterization of leucocin A-UAL 187 and cloning of the bacteriocin gene from Leuconostoc gelidum. Journal of Bacteriology 173, 7491-7500.

Héchard, Y., Dherbomez, M., Cenatiempo, Y. \& Letellier, F. (1990). Antagonism of lactic acid bacteria from goat's milk against pathogenic strains assessed by the 'sandwich method'. Letters in Applied Microbiology 11, 185-188.

Holo, H., Nilssen, O. \& Nes, I. F. (1991). Lactococcin A, a new bacteriocin from Lactococcus lactis subsp. cremoris: isolation and characterization of the protein and its gene. Journal of Bacteriology 173, 3879-3887.

JoERGER, M. C. \& K LAENhAMmer, T. R. (1986). Characterization and purification of helveticin $\mathrm{J}$ and evidence for a chromosomally determined bacteriocin produced by Lactobacillus helveticus 481 . Journal of Bacteriology 167, 439-446.

Joerger, M. C. \& Klaenhammer, T. R. (1990). Cloning and nucleotide sequence of the Lactobacillus helveticus 481 gene encoding the bacteriocin helveticin J. Journal of Bacteriology 172, 6339-6347.

Johnson, J. L., Doyle, M. P. \& CAssens, R. G. (1990). Listeria monocytogenes and other Listeria spp. in meat and meat products. A review. Journal of Food Protection 53, 81-91.

Klaenhammer, T. R. (1988). Bacteriocins of lactic acid bacteria. Biochimie 70, 337-349.

Kordel, M., Benz, R. \& SAHL, H.-G. (1988). Mode of action of the staphylococcinlike peptide Pep5: voltage-dependent depolarization of bacterial and artificial membranes. Journal of Bacteriology 170, 84-88.

MERILl, C. R. (1990). Silver staining of proteins and DNA. Nature, London 343, 779-780.

Mortvedt, C. I., Nissen-Meyer, J., Sletten, K. \& Nes, I. F. (1991). Purification and amino-acid sequence of Lactocin $\mathrm{S}$, a bacteriocin produced by Lactobacillus sake L45. Applied and Environmental Microbiology 57, 1829-1834.

Muriana, P. M. \& Klaenhammer, T. R. (1991). Purification and partial characterization of Lactacin F, a bacteriocin produced by Lactobacillus acidophilus 11088. Applied and Environmental Microbiology 57, 114-121.

Pattus, F., Massotte, D., Wilsem, H. U., Lakey, J., Tsernoglou, D., TUCKer, A. \& PARKer, M. W. (1990). Colicins: prokaryotic killer-pores. Experientia 46, 180-192.

Piard, J. C. \& Desmazeaud, M. (1991). Inhibiting factors produced by lactic acid bacteria. Oxygen metabolites and catabolism endproducts. Lait 71, 1-17.

SCHÄGGER, H. \& VON JAGOW, G. (1987). Tricine-sodium dodecyl sulfate-polyacrylamide gel electrophoresis for the separation of proteins in the range from 1 to $100 \mathrm{kDa}$. Analytical Biochemistry 166, 369-379.

SCOPES, R. K. (1988). Methods for measuring protein concentration. In Protein Purification. Principles and Practice, pp. 278-283. Edited by C. R. Cantor. New York: Springer Verlag.

Stiles, M. E. \& Hastings, J. W. (1991). Bacteriocin production by lactic acid bacteria : potential for use in meat preservation. Trends in Food Science and Technology 2, 247-251.

TAGg, J. R., Dajani, A. S. \& WanNamaker, L. W. (1976). Bacteriocins of Gram-positive bacteria. Bacteriological Reviews 40, 722-756.

Van Belkum, M. J., Kok, J., Venema, G., Holo, H., Nes, I. F., KonINGs, W. N. \& ABEE, T. (1991). The bacteriocin Lactococcin A specifically increases permeability of lactococcal cytoplasmic membranes in a voltage-independent, protein-mediated manner. Journal of Bacteriology 173, 7934-7941. 